\title{
Fungsi Pelanggaran Maksim Prinsip Kesantunan Pada Komentar Berita Online di Fanspage Facebook merdeka.com
}

\author{
Qurratul A'ini \\ Universitas Sebelas Maret, Surakarta, Indonesia
}

\begin{tabular}{|c|c|}
\hline Article Info & ABSTRACT \\
\hline Article history: & \multirow{11}{*}{$\begin{array}{l}\text { This article discusses about maxim violation function of politeness } \\
\text { principle in the Fanspage Facebook comments of online news Merdeka. } \\
\text { Com. Data in form of utterances were collected from Fanspage Facebook } \\
\text { merdeka.com with politic rubric 23rd-24th September 2016. The result of } \\
\text { this research shows that the utterances that violate the maxims of } \\
\text { politeness principle are in form of assertive, directive and expressive. } \\
\text { Assertive has } 2 \text { sub function, they are "assert" and "insinuate". Directive } \\
\text { has } 3 \text { sub function, they are "giving advice", "prohibit" and "ask". } \\
\text { Expressive has } 6 \text { sub function, they are "blame", "arraign", "swear", } \\
\text { "ridicule", "criticize", "underestimate" and "hope". The dominant function } \\
\text { is assertive with sub function "assert". }\end{array}$} \\
\hline Submitted July 26, 2017 & \\
\hline Revised April 19, 2018 & \\
\hline Accepted April 25, 2018 & \\
\hline Published November 21, 2018 & \\
\hline Keywords: & \\
\hline Politeness principle & \\
\hline The violation maxim & \\
\hline Compliance macim & \\
\hline Functions of violation & \\
\hline Speech act & \\
\hline
\end{tabular}

\section{Corresponding Author:}

Qurratul A'ini,

Postgraduate Program of Universitas Sebelas Maret, Surakarta, Indonesia

Jl. Ir. Sutami 36 A, Kentingan, Surakarta, Indonesia.

Email: qurrotulain07@gmail.com

\section{PENDAHULUAN}

Suwarna (2002:4) mengungkapkan bahwa bahasa merupakan alat utama untuk berkomunikasi dalam kehidupan manusia, baik secara individu maupun kolektif. Didalam berbahasa terdapat penutur dan mitra tutur di dalamnya. Hal ini bertujuan untuk mengatur tindakan berbahasa dengan kaidah- kaidah tertentu antar peserta pertuturan. Di dalam berkomunikasi dapat dilakukan dengan dua cara yaitu komunikasi lisan dan tulisan. Perkembangan komunikasi ini juga dipengaruhi oleh perkembangan teknologi yang ada saat ini. Perkembangan ini ditandai dengan bahwa komunikasi tidak harus selalu dilakukan secara bertatap muka, namun bisa juga dengan melibatkan teknologi di dalamnya. Salah satu contoh teknologi tersebut adalah facebook. Segala ide, gagasan dan juga ekpresinya bisa disampaikan oleh penutur kepada mitra tutur melalui media sosial yang bernama facebook ini.

Budiawan (2012) mengatakan bahwa apapun yang dibicarakan orang di facebook, situs ini terbukti sukses menjadi sebuah media komunikasi baru yang sanggup merajut relasi sosial. Facebook ini juga menjadi jejaring sosial paling modern untuk menjaga relasi sosial oleh generasi sekarang. Pengguna internet yang semakin hari semakin meningkat, khususnya para pengguna media sosial facebook ini menjadikan banyak kalangan memanfaatkan keberadaannya. Hal ini juga dimanfaatkan oleh beberapa media untuk menyampaikan berita dengan cepat kepada khalayak, salah satunya yaitu situs berita Merdeka. Com. 
Merdeka. Com merupakan hasil kolaborasi antara media dan teknologi. Merdeka.Com ini dibangun oleh perusahaan teknologi yang terdiri dari orang- orang yang sudah berkompeten di dalamnya. Merdeka.com tersebut kemudian juga membuat Facebook fanspage yang sudah disukai oleh 3. 778. 530 orang (https:// www. facebook.com/ MDKcom/ about?). Rubrik berita yang ditampilkan bermacam- macam, diantaranya Politik, Ekonomi, Hukum, Kriminal, Olahraga, Otomotif, Gaya hidup, Entertainment, Hiburan nasional hingga mancanegara. Berbagai rubrik berita tersebut dapat dibaca di beranda Facebook Merdeka. Com sehingga memudahkan pengikut (followers) facebook untuk memberikan komentar terkait isi berita.

Dalam sebuah komunikasi, prinsip yang sangat diperhatikan yaitu prinsip kesantunan karena hal ini sangat berhubungan dengan persoalan yang sifatnya interpersonal. Prinsip kesantunan menurut Leech (2011: 2016-207) terdiri dari 6 maksim yaitu (1) maksim kearifan (tact maxim), (2) maksim kedermawanan (Generosity maxim), (3) Maksim pujian (approbation maxim), (4) maksim kerendahan hati (modesty maxim), (5) maksim kesepakatan (agreement maxim), (6) maksim simpati (sympathy maxim).

Berdasarkan prinsip kesantunan tersebut, komentar berita akan diklasifikan khusus apakah melanggar ataukah mematuhi maksim. Pada kategori tuturan yang melanggar maksim akan diklasifikan lebih lanjut fungsi dari pelanggarannya tersebut. Adapun fungsi tuturan, penelitian ini menggunakan teori Searle (1979) yang membagi lima macam bentuk tuturan yaitu: (1) Asertif, (2) Direktif, (3) Ekspresif, (4) Komisif, (5) Deklaratif. Dari jenis tuturan tersebut kemudian diklasifikasikan kembali sub fungsinya. Perihal fungsi pelanggaran maksim ini sebelumnya sudah pernah dilakukan oleh Franzischa (2013), Di dalam penelitiannya disebutkan beberapa fungsi pelanggaran yang ditemukan yaitu "mengejek", "meminta", "mengeluh", "mengemukakan pendapat", "memerintah", "menyatakan" dan "membual". Penelitian lainnya terkait fungsi pelanggaran juga pernah dilakukan oleh Afifah (2016). Dalam penelitiannya fungsi pelanggaran yang ditemukan yaitu dalam bentuk tindak tutur asertif, direktif, ekspresif dan komisif

Pada penelitian ini, peneliti mengkaji prinsip kesantuan pada komentar media berita online Merdeka.com yang difokuskan pada beberapa berita politik terpilih. Belum adanya penelitian mengenai komentar pada berita online melalui fanspage facebook juga menjadi pertimbangan peneliti. Lebih dari itu, terkait fungsi pelanggaran juga ditemukan beragam fungsi pelanggaran yang berbeda dari penelitian sebelumnya.

\section{TEORI DAN METODOLOGI}

Pragmatik merupakan cabang linguistik yang mempelajari bahasa yang digunakan untuk berkomunikasi dalam situasi tertentu. Pragmatik memperlakukan makna sebagai suatu hubungan yang melibatkan tiga segi (triadic) (Leech, 2011:8). Dengan demikian, dalam pragmatik makna diberi definisi dalam hubungannya dengan penutur atau pemakai bahasa. Namun untuk tujuan- tujuan linguistiknya, Leech akan memberi batasan yang baru pada pragmatik, yaitu sebagai studi tentang makna dalam hubungannya dengan situasi- situasi ujar.

Dalam pragmatik, ada yang dinamakan dengan prinsip kesantunan. Berbicara tidak selamanya berkaitan dengan masalah yang bersifat tekstual, tetapi sering pula berhubungan dengan persoalan yang bersifat interpersonal. Sebagai retorika interpersonal, pragmatik membutuhkan prinsip lain yakni prinsip kesopanan (Wijana \& Rohmadi, 2011: 53). Maksim- maksim kesantunan adalah yaitu: (I) Maksim Kearifan (Tact Maxim), (II) Maksim kedermawanan (Generosity Maxim), (III) Maksim pujian (Approbation 
Maxim), (IV) Maksim kerendahan hati (Modesty Maxim), (V) Maksim kesepakatan (Agreement Maxim), (VI) Maksim Simpati (Sympathy Maxim).

Maksim kearifan memiliki dua segi, yaitu segi negatif 'Buatlah kerugian lawan tutur sekecil mungkin', dan kedua, segi positif 'Buatlah keuntungan lawan tutur sebesar mungkin'. Segi yang kedua, segi positif tidak begitu penting, tetapi merupakan akibat yang wajar dari segi pertama (Leech, 2011: 170). Maksim kedermawanan " buatlah keuntungan diri sendiri sekecil mungkin, buatlah kerugian diri sendiri sebesar mungkin” (Leech, 2011: 209). Maksim pujian kategorinya adalah "Kecamlah orang lain sedikit mungkin, pujilah orang lain sebanyak mungkin". Pada maksim ini aspek negatifnya yang lebih penting yaitu "jangan mengatakan hal- hal yang tidak menyenangkan mengenai orang lain, terutama mengenai lawan tutur (t) (Leech, 2011: 212).

Maksim kerendahan hati kategorinya yaitu "Pujilah diri sendiri sedikit mungkin, kekecamlah diri sendiri sebanyak mungkin" (Leech, 2011: 214). Maksim kesepakatan memiliki dua segi yaitu, pertama "orang cenderung melebih- lebihkan kesepakatannya dengan orang lain", kedua "mengurangi ketidaksepakatannya dengan ungkapanungkapan penyesalan, kesapakatan sebagian, dan sebagainya (Leech, 2011: 217). Maksim simpati menjelaskan mengapa ucapan selamat dan ucapan belasungkawa adalah tindak ujar yang sopan dan hormat, walaupun ucapan belasungkawa mengungkapkan keyakinan penutur yang bagi petutur merupakan keyakinan yang negatif (Leech, 2011: 218).

Jenis penelitian ini adalah penelitian deskriptif-kualitatif. Lokasi penelitian adalah facebook fanspage Merdeka.com pada rubrik berita politik yaitu berita pada tanggal 23 September 2016 dengan judul berita (Usung Agus, SBY pernah bilang TNI jangan bercitacita jadi gubernur) dan 24 September 2016 (Wefie seru Cagub-Cawagub DKI jelang pemeriksaan kesehatan). Sumber data penelitian ini adalah fanspage facebook Merdeka.com dengan topik berita politik terpilih yaitu berita tanggal 23 dan 24 September 2016. Data dalam penelitian ini adalah data kebahasaan yang berupa satuan- satuan lingual yang terdapat dalam komentar berita yang diambil. Satuan- satuan lingual tersebut berwujud kata- kata, kalimat- kalimat tuturan para followers. Teknik pengumpulan data juga dilakukan dengan metode dokumentasi. Metode dokumentasi dijabarkan menjadi pengumpulan data, reduksi data, penampilan data dan verifikasi data (Miles dan Huberman, 2014: 10-11). Validitas data penelitian ini menggunakan triangulasi sumber dan triangulasi metode. Triangulasi sumber data pada penelitian ini berupa dokumen meliputi tuturan tertulis komentar berita di facebook Merdeka.com, buku- buku, dan jurnal ilmiah terkait penelitian ini tentang prinsip kesantunan. Penelitian kualitatif ini menggunakan model analisis menurut Spradley (1980) dalam Santosa (2010: 66) yaitu dibagi dalam empat tahapan besar: analisis domain, analisis taksonomi, analisis komponensial, analisis tema budaya.

\section{HASIL DAN PEMBAHASAN}

Tuturan menurut Searle terbagi menjadi 5 (lima) macam yaitu Asertif (Assertives), Direktif (Directives), Komisif (Commissive), Ekspresif (Expressives), Deklarasi (Declarations). Di dalam penelitian ini, tuturan komisif dan deklarasi tidak ditemukan, sementara tuturan lainnya ada dalam penelitian. Beberapa fungsi yang ditemukan masih memiliki sub fungsi. Fungsi asertif memiliki dua sub fungsi yaitu "menyatakan" dan "menyindir", fungsi ekspresif memiliki sub fungsi "mencela", "menyalahkan", "mengumpat", "mengolok", "mengecam", "meremehkan" dan "berharap". Adapun fungsi direktif juga memiliki beberapa sub fungsi yaitu "menasehati", "melarang" dan "bertanya". 


\section{A. Asertif}

Tindak tutur tutur asertif adalah tindak tutur yang mengikat penuturnya kepada kebenaran proposisi atas hal yang dikatakannya. Dalam penelitian ini, ditemukan beberapa data yang melanggar merupakan tindak tutur asertif. Terdapat dua sub fungsi yang ditemukan dalam fungsi asertif yaitu sub fungsi "menyatakan" dan sub fungsi "menyindir. Berikut penjelasan beserta contoh datanya.

\section{Menyatakan}

Beberapa pelanggaran yang ditemukan dalam penelitian ini menggunakan tuturan asertif dengan maksud menyatakan sesuatu. Contoh data yang termasuk dalam ketegori ini adalah sebagai berikut.

Topik berita

SBY pernah mengingatkan para perwira lulusan akademi TNI dan Polri sebaiknya tidak bercita- cita menjadi kepala daerah mulai dari tingkat gubernur, bupati dan wali kota.

Komentar Kalo Sby jangankan ludahnya, kotorannya sendiripun akan dijilat Demi keserakahan dan kekuasaan.(002) Ingat dulu bgm dia digebukin oleh Prabowo saat di Akmil? (003) Tp sekarang bersanding demi APBD DKI yg menggiurkan (004)

004/ Melanggar- Kearifan/ TTD- Asertif- menyatakan/ MDK.COM/23 Sept 16

Tuturan dengan no data 04 di atas adalah salah satu tuturan yang dikategorikan melanggar maksim kearifan karena di dalamnya mengandung kerugian terhadap orang lain. Tuturan 04 tersebut merupakan pernyataan yang diberikan oleh komentator setelah ia mengungkapkan dengan kalimat pertanyaan sebelumnya. Dengan demikian, tuturan yang melanggar tersebut dikategorikan sebagai tuturan asertif "menyatakan". Contoh data lainnya yang termasuk dalam kategori fungsi asertif "menyatakan" adalah sebagai berikut.

Topik berita $\quad$ SBY pernah mengingatkan para perwira lulusan akademi TNI dan Polri sebaiknya tidak bercita- cita menjadi kepala daerah mulai dari tingkat gubernur, bupati dan wali kota.

Komentar Menumbangkan Ahok adalah kewajiban (006) yang penting ijtihad itu ada, kalah menang urusan belakang, harusnya risma yang maju (007)

006/ Melanggar- Kerendahan hati/ TTD- Asertif- menyatakan/ MDK.COM/23 Sept 16

Tuturan $06 \mathrm{di}$ atas merupakan tuturan yang dikategorikan melanggar maksim kerendahan hati. Adapun fungsi pelanggarannya disampaikan dengan tuturan asertif dengan sub fungs "menyatakan". Hal tersebut merupakan sebuah pernyataan komentator yang disampaikan kepada orang lain/ komentator lainnya.

\section{Menyindir}

Sub fungsi lainnya dari tuturan asertif yang ditemukan dalam penelian ini adalah "menyindir". Berikut adalah contoh data yang termasuk dalam kategori "menyindir".

Topik berita

SBY pernah mengingatkan para perwira lulusan akademi TNI dan Polri sebaiknya tidak bercita- cita menjadi kepala daerah mulai dari tingkat gubernur, bupati dan wali kota. 
Komentar

Jadi ingat jargon Katakan TIDAK pada korupsi Padahal pada korupsi semua (045)

045/ Melanggar- Kearifan/ TTD- Asertif - menyindir/ MDK.COM/23 Sept 16

Tuturan dengan no data 45 seperti pada kutipan di atas dikategorikan sebagai tuturan yang melanggar maksim kearifan. Tuturan tersebut disampaikan dalam bentuk tuturan "asertif" dengan sub "menyindir". Dalam menanggapi berita tanggal 23 September 2016, tuturan no 45 di atas disampaikan oleh komentator dengan sindiran. Sindiran tersebut ditujukan pada SBY yang memiliki jargon"Katakan Tidak Pada Korupsi" saat masih menjabat sebagai presiden. Contoh data serupa yang juga dikategorikan sebagai fungsi menyindir adalah sebagai berikut.

Topik berita $\quad$ SBY pernah mengingatkan para perwira lulusan akademi TNI dan Polri sebaiknya tidak bercita- cita menjadi kepala daerah mulai dari tingkat gubernur, bupati dan wali kota.

Komentar

Slogan demokrat terbaru, tetap tdk pernah menang lanjutkan korupsi (049)

049/ Melanggar- Kerendahan hati TTD- Asertif - menyindir/ MDK.COM/23 Sept 16

Dalam menaggapi isi berita tanggal 23 September 2016, data no 49 di atas dikategorikan melanggar maksim kerendahan hati. Di dalam pelanggaran tersebut terkandung fungsi "menyindir". Hal ini dapat diketahui dari satuan lingual yang menandainya yaitu "Slogan demokrat terbaru, tetap tdk pernah menang lanjutkan korupsi". Tuturan tersebut adalah untuk menyindir partai Demokrat yang mana partai tersebut dipimpin oleh SBY. Selain dua contoh di atas, contoh data lainnya yang termasuk dalam kategori "menyindir" juga dicontohkan seperti pada kutipan berikut.

Topik berita $\quad$ SBY pernah mengingatkan para perwira lulusan akademi TNI dan Polri sebaiknya tidak bercita- cita menjadi kepala daerah mulai dari tingkat gubernur, bupati dan wali kota.

Komentar Penak Jamanku to?

\section{Korupsi Gampang (100)}

100/ Melanggar- Pujian/ TTD- Ekspresif - menyindir/ MDK.COM/23 Sept 16

Data no 100 juga dikategorikan mengandung fungsi "menyindir" dan di dalamnya juga termasuk kategori melanggar maksim pujian. Tuturan tersebut adalah salah satu tanggapan komentator pada berita tanggal 23 September 2016. Tuturan "Penak Jamanku to? Korupsi Gampang" adalah bentuk sindiran yang ditujukan pada SBY yang mungkin menurut penilaian komentator saat masa jabatan SBY menjadi presiden banyak terjadi korupsi.

\section{B. Direktif}

Fungsi lain yang ditemukan dalam penelitian ini adalah fungsi direktif. Direktif adalah suatu ilokusi yang bertujuan menghasilkan suatu efek yang akan dilakukan. Dalam hal ini terdapat 3 sub fungsi direktif yang ditemukan dalam penelitian ini diantaranya "menasehati", "melarang" dan "bertanya". 


\section{Menasehati}

Nasihat adalah ajaran atau pelajaran baik; anjuran (petunjuk, peringatan, teguran) yang baik. Menasihati berarti memberi nasihat (kepada). Contoh data yang tergolong dalam fungsi direktif dengan sub "menasehati" adalah sebagai berikut.

Topik berita $\quad$ SBY pernah mengingatkan para perwira lulusan akademi TNI dan Polri sebaiknya tidak bercita- cita menjadi kepala daerah mulai dari tingkat gubernur, bupati dan wali kota.

Komentar Ujung ujung nya tanah pri bumi ambil alih dgn ganti rugi atau jual beli ga setimpal ama orang umum nya etnis tionghoa (015) Hati hati warga jkt jgn sampe salah pilih (016) Jgn mau iming2 serba kartu gratis (017)

017/ Melanggar- Kesepakatan/ TTD- Direktif- Menasehati/ MDK.COM/23 Sept 16

Tuturan dengan no data 17 seperti pada kutipan di atas merupakan tuturan yang melanggar maksim kesepakatan karena tuturan tersebut adalah tuturan yang memaksimalkan ketidakcocokan. Tuturan tersebut disampaikan dengan tuturan direktif dengan sub "menasehati". Komentator membei nasehat kepada semua warga Jakarta agar lebih berhati- hati dalam memilih Calon Gubernur dan jangan terkecoh dengan imingiming apapun termasuk dengan serba kartu gratis.

\section{Melarang}

Sub fungsi lainnya dari tuturan direktif yang ditemukan dalam penelitian yaitu "melarang". Melarang adalah memerintahkan supaya tidak melakukan sesuatu; tidak memperbolehkan berbuat sesuatu. Contoh data yang termasuk dalam kategori "melarang" adalah sebagai berikut.

Topik berita

SBY pernah mengingatkan para perwira lulusan akademi TNI dan Polri sebaiknya tidak bercita- cita menjadi kepala daerah mulai dari tingkat gubernur, bupati dan wali kota.

Komentar

Sebagai umat islam kita wajib untuk memilih pemimpin islam pula (018) Jangan memikirkan tentang kebnyakan pemimpin islam yg korupsi (019) Yg islam yg sudah tau, ada aturan untuk tdak mengambil hak org lain aja masih korupsi (020)

019/ Melanggar- Kesepakatan/ TTD- Direktif- melarang/ MDK.COM/23 Sept 16

Tuturan dengan no data 19 adalah satu contoh data yang disampaikan dengan tuturan direktif dengan sub tuturan "melarang". Tuturan tersebut juga termasuk dalam kategori melanggar maksim kesepakatan. Dengan demikian, fungsi pelanggarannya yaitu "melarang". Satuan lingual yang menandainya yaitu "Jangan memikirkan". Satuan lingual tersebut adalah tanda larangan yang ditujukan pada semua umat islam.

\section{Bertanya}

Sub fungsi lainnya dari tuturan direktif yaitu "bertanya". Bertanya adalah meminta keterangan yang berpa penjelasan dan sebagainya; meminta supaya diberitahu. Dalam bertanya biasanya diikuti dengan $5 \mathrm{~W}+1 \mathrm{H}$ sebagai penandanya. Contoh data yang termasuk dalam kategori "bertanya" adalah sebagai berikut. 
Topik berita

Komentar
SBY pernah mengingatkan para perwira lulusan akademi TNI dan Polri sebaiknya tidak bercita- cita menjadi kepala daerah mulai dari tingkat gubernur, bupati dan wali kota.

Pye to mbah beye?

Knp gak duet ama abaqh skalian (070)

16

070/ Melanggar- Kerendahan hati/ TTD- Direktif - bertanya/ MDK.COM/23 Sept

Tuturan dengan no data 70 adalah salah satu contoh tuturan direktif dengan sub "bertanya". Satuan lingual yang menandainya yaitu "kenapa". Tuturan tersebut juga dikategorikan sebagai tuturan yang melanggar kerendahan hati karena komentator memaksimalkan ketidakhormatan pada orang lain yaitu SBY.

\section{Ekspresif}

Fungsi ekpresif adalah fungsi ilokusi yang mengutarakan sikap psikologis penutur terhadap keadaan yang tersirat. Terdapat beberapa sub fungsi yang ditemukan pada sub fungsi ekspresif diantaranya; "mencela", "menyalahkan", "mengumpat", "mengolok", "mengecam" dan "meremehkan".

\section{Mencela}

Mencela adalah salah satu sub tuturan ekspresif yang ditemukan dalam penelitian ini. Mencela adalah mencatat, mengkritik, menghina, mengatakan bahwa ada celanya. Cela adalah sesuatu yang menyebabkan kurang sempurna, cacat, kekurangan. Data yang termasuk dalam kategori "mencela" dicontohkan pada kutipan berikut.

Topik berita $\quad$ SBY pernah mengingatkan para perwira lulusan akademi TNI dan Polri sebaiknya tidak bercita- cita menjadi kepala daerah mulai dari tingkat gubernur, bupati dan wali kota.

Komentar $\quad$ Wkwkwkwk beye gt loh...katakan tidak padahal iya.... (093)

093/ Melanggar- Pujian/ TTD- Ekspresif - mencela/ MDK.COM/23 Sept 16

Tuturan no 93 di atas dikategorikan sebagai bentuk tuturan ekspresif "mencela" komentator pada orang lain yaitu SBY. Tuturan di atas juga termasuk tuturan yang melanggar maksim pujian. Contoh lain yang termasuk dalam kategori tuturan ekspresif "mencela " adalah sebagai berikut.

Topik berita $\quad$ SBY pernah mengingatkan para perwira lulusan akademi TNI dan Polri sebaiknya tidak bercita- cita menjadi kepala daerah mulai dari tingkat gubernur, bupati dan wali kota.

Komentar

Jilat ludah sendiri, jorok (103)

103/ Melanggar- Pujian/ TTD- Ekspresif - mencela/ MDK.COM/23 Sept 16

Tuturan 103 di atas juga contoh tuturan yang melanggar maksim pujian karena mengandung perkataan negatif yang tidak menyenangkan orang lain yaitu SBY. Adapun bentuk tuturannya yaitu ekspresif dengan sub tuturan "mencela".

\section{Menyalahkan}

Sub lainnya dari fungsi ekspresif yaitu "menyalahkan". Menyalahkan adalah menyatakan (memandang, menganggap) salah. Berikut adalah contoh tuturan yang termasuk dalam sub "menyalahkan". 
Topik berita

Komentar
SBY pernah mengingatkan para perwira lulusan akademi TNI dan Polri sebaiknya tidak bercita- cita menjadi kepala daerah mulai dari tingkat gubernur, bupati dan wali kota.

Ah lu hok parte muslim jdi pecah tu (042)

042/ Melanggar- Kedermawanan/ TTD- Ekspresif - menyalahkan/ MDK.COM/23 Sept 16

Tuturan di atas dengan no data 42 termasuk dalam kategori melanggar maksim kedermawanan. Pelanggaran tersebut dituturkan dengan jenis tuturan ekspresif dengan sub "menyalahkan". Dapat dilihat pada tuturan bahwa komentatir menyalahkan orang lain yaitu Ahok karena sudah menyebabkan pecahnya partai muslim.

\section{Mengumpat}

Sub tindak tutur ekspresif selanjutnya yaitu "mengumpat". Mengumpat adalah mengeluarkan umpatan; memburuk- burukkan orang; mengeluarkan kata- kata keji (kotor) karena marah (jengkel, kecewa, dan sebagainya). Di dalam data yang melanggar juga ditemukan ungkapan "mengumpat". Contoh datanya adalah sebagai berikut.

Topik berita

SBY pernah mengingatkan para perwira lulusan akademi TNI dan Polri sebaiknya tidak bercita- cita menjadi kepala daerah mulai dari tingkat gubernur, bupati dan wali kota.

Komentar SUEK lu Hok (043)

043/ Melanggar- Kerendahan hati/ TTD- Ekspresif - mengumpat/ MDK.COM/23 Sept 16

Tuturan dengan no data 43 adalah tuturan yan melanggar maksim kerendahan hati. Tuturan disampaikan dengan tuturan ekspresif dengan sub tuturan "mengumpat". Komentator mengeluarkan kata- kata kotor tersebut ditujukan pada Ahok. Selain contoh tersebut, contoh data lainnya yang termasuk dalam kategori mengumpat dicontohkan pada kutipan data berikut.

Topik berita

Komentar

SBY pernah mengingatkan para perwira lulusan akademi TNI dan Polri sebaiknya tidak bercita- cita menjadi kepala daerah mulai dari tingkat gubernur, bupati dan wali kota.

091/ Melanggar- Pujian/ TTD- Ekspresif - mengumpat/ MDK.COM/23 Sept 16

Data no 91 di atas dikategorikan melanggar maksim pujian dengan fungsi "mengumpat" yang terkandung di dalamnya. Satuan lingual "anak bodoh" merupakan umpatan yang dilontarkan oleh komentator dalam menanggapi isi berita tanggal 23 September 2016.

\section{Mengolok}

Sub tindak tutur lainnya dari tindak tutur "ekspresif" yang ditemukan dalam penelitian ini yaitu "mengolok". Mengolok adalah mempermainkan dengan perkataan (seperti mengejek). Contoh data yang yang melanggar maksim dan termasuk dalam sub tindak tutur "mengolok" adalah sebagai berikut.

Topik berita

SBY pernah mengingatkan para perwira lulusan akademi TNI dan Polri sebaiknya tidak bercita- cita menjadi kepala daerah mulai dari tingkat gubernur, bupati dan wali kota.

Komentar

Senjata makan tuan dgn ucapan nya (066) Nyata nya sby tdk konsekuen dgn ucapan nya (067) Preet (068) 
068/ Melanggar- Kerendahan hati/ TTD- Ekspresif - mengolok/ MDK.COM/23 Sept 16

Tuturan no 68 di atas adalah salah satu komentar dari komentator dalam menanggapi berita tanggal 23 September 2016. Tuturan tersebut dikategorikan sebagai tuturan yang melanggar maksim kerendahan hati. Tuturan disampaikan dengan tuturan ekspresif dan sub tuturannya "mengolok". Satuan lingual "Preet" adalah bentuk olokan komentator pada SBY yang menurutnya tidak konsekuen dengan ucapannya.

\section{Mengecam}

Sub tindak tutur ekspresif lainnya yaitu "mengecam". Mengecam adalah menyelidiki (mengamat-amati) dengan teliti, mengkritik, mencela. Berdasarkan definisi tersebut, beberapa contoh data yang termasuk dalam kategori mengecam adalah sebagai berikut. Contoh data diperoleh dari komentar berita tanggal 23 September 2016 dengan kutipan sebagai berikut.

Topik berita $\quad$ SBY pernah mengingatkan para perwira lulusan akademi TNI dan Polri sebaiknya tidak bercita- cita menjadi kepala daerah mulai dari tingkat gubernur, bupati dan wali kota.

Komentar Kapir HARAM...! (088)

088/ Melanggar- Kerendahan hati/ TTD- Ekspresif - mengecam/ MDK.COM/23 Sept 16

Tuturan 88 di atas merupakan tuturan yang melanggar maksim kerendahan hati karena di dalamnya peserta pertuturan memaksimalkan ketidakhormatan pada orang lain. Adapun bentuk tuturannya yaitu ekspresif dengan sub "mengecam".

\section{Meremehkan}

Selain yang telah disebutkan, sub tindak tutur ekspresif lainnya yang ditemukan dalam penelitian ini yaitu "meremehkan". Berikut adalah contoh data yang termasuk dalam kategori "meremehkan".

Topik berita $\quad$ SBY pernah mengingatkan para perwira lulusan akademi TNI dan Polri sebaiknya tidak bercita- cita menjadi kepala daerah mulai dari tingkat gubernur, bupati dan wali kota.

Komentar

Beyeee beyeee (121)

121/ Melanggar- Kearifan/ TTD- Ekspresif - meremehkan/ MDK.COM/23 Sept 16

Tuturan dengan no data 121 seperti pada kutipan di atas adalah tuturan yang dikategorikan melanggar maksim kearifan. Adapun jenis tindak tuturnya yaitu ekspresif dengan sub tindak tutur "meremehkan". Tuturan tersebut diungkapkan oleh komentator untuk meremehkan SBY yang kemudian disebut dengan "beyee beyee". Hal ini terkait dengan pencalonan Agus bahwa SBY pernah mengatakan bahwa sebaiknya lulusan perwira TNI tidak bercita- cita menjadi kepala daerah, namun dalam hal ini Agus yang merupakan anak dari SBY sendiri harus pensiun dini dari karir kemiliterannya karena diusung untuk menjadi calon gubernur.

\section{Berharap}

Sub fungsi terakhir dari fungsi ekspresif yaitu "Berharap". Berharap adalah keinginan supaya terjadi; meminta supaya. Tuturan yang tergolong dalam fungsi ekspresif "berharap" dicontohkan pada kutipan berikut.

Topik berita $\quad 3$ pasangan calon gubernur dan wakil gubernur melakukan wefie seru jelang tes kesehatan. 
Komentar Semoga tidak dihilangkan kewarasannya oleh para timses (147)

147/ Melanggar- Kearifan/ TTD- Ekspresif- berharap/ MDK.COM/24 Sept 16

Tuturan dengan no data 147 di atas merupakan komentar dari berita tanggal 24 September 2016. Tuturan tersebut termasuk dalam kategori melanggar maksim kearifan karena merugikan orang lain yaitu Tim Sukses Pilkada DKI. Adapun fungsi pelanggarannya yaitu ekspresif dengan sub fungsi "berharap".

Berdasarkan penjelasan di atas, fungsi pelanggaran yang ditemukan dalam penelitian ini yakni fungsi asertif, direktif dan ekspresif. Klasifikasi data dengan fungsi pelanggarannya secara jelas dapat dilihat pada tabel berikut.

Tabel 1. Kategori Fungsi Pelanggaran

Berita Tanggal 23 dan 24 September 2016

\begin{tabular}{|c|c|c|c|c|}
\hline No & 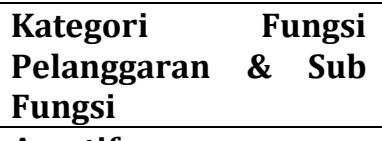 & No data & Jumlah & Persentase \\
\hline \multirow{3}{*}{1.} & Asertif & & & \\
\hline & Menyatakan & $\begin{array}{l}4,6,8,10,11,15,20,21,32,94,96, \\
110,117,120,145,157,164,173, \\
174,177,184\end{array}$ & 21 & $31,3 \%$ \\
\hline & Menyindir & $\begin{array}{l}22,39,40,45,46,49,100,119,133, \\
134\end{array}$ & 10 & $14,9 \%$ \\
\hline \multirow{4}{*}{2.} & Direktif & & & \\
\hline & Menasehati & 17 & 1 & $1,49 \%$ \\
\hline & Melarang & $19,55,106$ & 3 & $4,47 \%$ \\
\hline & Bertanya & 70,21 & 2 & $2,98 \%$ \\
\hline \multirow{8}{*}{3.} & Ekspresif & & & \\
\hline & Mencela & $\begin{array}{l}26,52,66,67,74,75,81,93,95,98, \\
102,103,107,118,123,165,181\end{array}$ & 17 & $25,3 \%$ \\
\hline & Menyalahkan & 42 & 1 & $1,49 \%$ \\
\hline & Mengumpat & $43,91,97$ & 3 & $4,47 \%$ \\
\hline & Mengolok & $62,65,68,84$ & 4 & $5,97 \%$ \\
\hline & Mengecam & $88,101,112$ & 3 & $4,47 \%$ \\
\hline & Meremehkan & 121 & 1 & $1,49 \%$ \\
\hline & Berharap & 147 & 1 & $1,49 \%$ \\
\hline & Jumlah & & 67 & $100 \%$ \\
\hline
\end{tabular}

Berdasarkan tabel 1 dapat diketahui bahwa fungsi asertif dengan sub fungsi "menyatakan" terdiri dari 21 data dengan presentase 31,3\%, fungsi asertif dengan sub fungsi "menyindir" sebanyak 10 data dengan presentase 14,9\%. Adapun fungsi direktif dengan sub fungsi "menasehati" sebanyak 1 data dengan presentase 1,49\%, fungsi direktif dengan sub fungsi "melarang" sebanyak 3 data dengan presentase $4,47 \%$ dan fungsi direktif dengan sub fungsi "bertanya" sebanyak 2 data dengan presentase 2,98\%. Untuk fungsi ekspresif dengan sub fungsi "mencela" terdiri dari 17 data dengan persentase 25,3 $\%$, fungsi ekspresif dengan sub fungsi "menyalahkan" sebanyak 1 data dengan persentase 1,49 \%, fungsi ekspresif dengan sub fungsi "mengumpat" sebanyak 3 data dengan persentase 25,3 \%, sub fungsi "mengolok" terdiri dari 4 data dengan persentase 5,97 \%, sub fungsi "mengecam" sebanyak 3 data dengan persentase 4,47\%, 1 data dengan persentase 1,49\% termasuk dalam sub fungsi "meremehkan" dan "berharap". 


\section{SIMPULAN}

Fungsi pelanggaran yang ditemukan dalam penelitian adalah "menyatakan" dan "menyindir" yang dinyatakan dalam tindak tutur asertif, fungsi "menasehati", "melarang" dan "bertanya" yang dinyatakan dalam bentuk tindak tutur direktif, Fungsi pelanggaran lainnya yaitu fungsi ekspresif yang meliputi "mencela", "menyalahkan", "mengumpat", "mengolok", "mengecam", "meremehkan", dan "berharap". Fungsi pelanggaran paling dominan yaitu fungsi asertif "menyatakan".

\section{DAFTAR PUSTAKA}

Afifah, N. (2016). Prinsip kerja sama, implikatur, dan daya pragmatik dalam acara tatap mata di Trans TV. (Tesis). Universitas Sebelas Maret, Surakarta.

Budiawan, O. (2012). Jangan melihat buku dari wajahnya. Jurnal Ranah, TH. II No.1 April 2012.

Franzischa L.W. (2013). Analisis pelanggaran prinsip sopan santun dalam komik Crayon Sinchan volume 2 karya Yoshito Usui. Jurnal Japanology, Vol 1, No 1, Sept 2012Feb 2013.

Leech, G. (2011). Prinsip- prinsip pragmatik. Jakarta: Universitas Indonesia Press.

Miles. M., Huberman. A., Saldana.J. (2014). Qualitative data analysis a methods sourcebook. Arizona: Arizona State University.

Santosa, R. (2014). Metode penelitian kualitatif kebahasaan. Universitas Sebelas Maret.

Searle. (1979). Expression anda meaning. Cambridge: Cambridge U.P.

Suwarna. (2002). Strategi penguasaan berbahasa. Yogyakarta: Adicita Karya Nusa.

Wijana, I.D.P., \& Rohmadi, M. (2011). Analisis wacana pragmatik kajian teori dan analisis. Surakarta: Yuma Pustaka.

https://www.facebook.com/MDKcom/about? diakses pada 20 September 2016. 